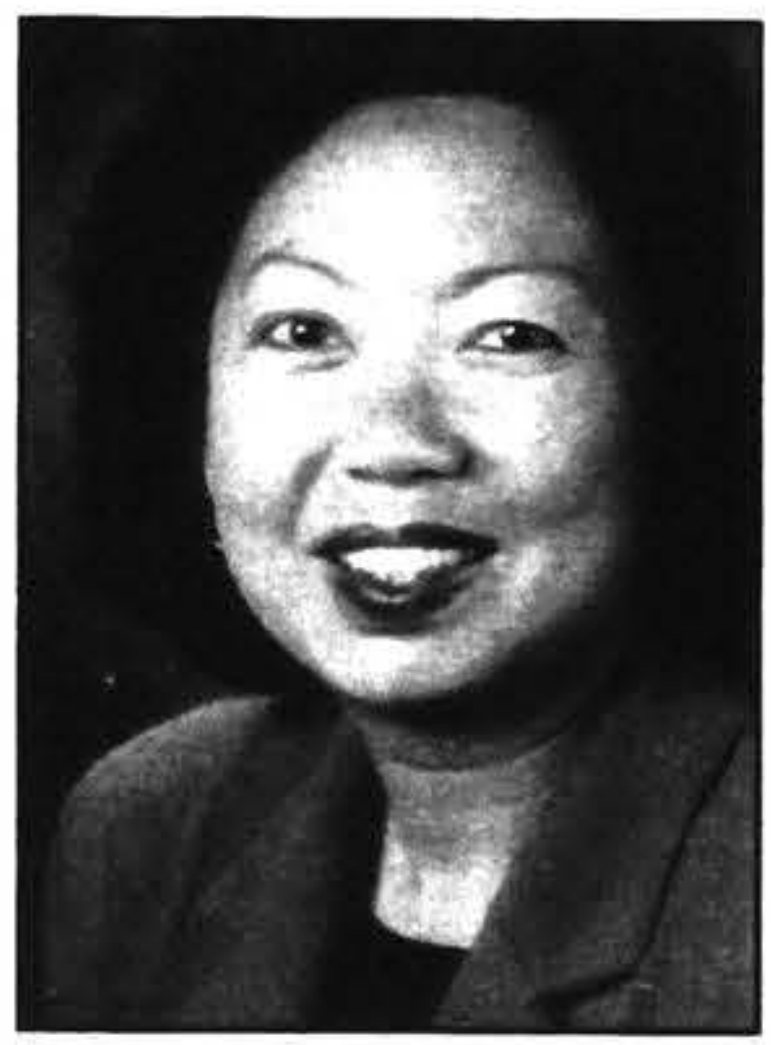

\title{
GIVE US A CHANCE: THE EMPLOYMENT EXPERIENCES OF NEW SETTLERS FROM EAST ASIA
}

\author{
Elsie S. Ho and Jacqueline M. Lidgard \\ Department of Geography \\ University of Waikato
}

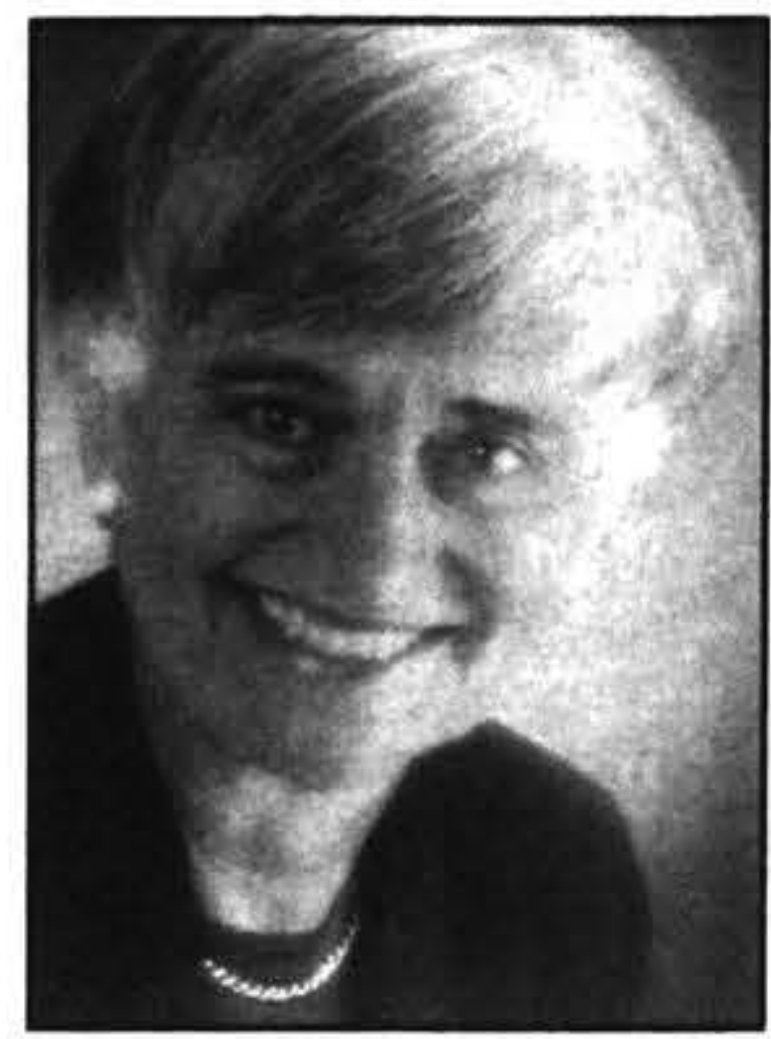

\begin{abstract}
Our research on new settlers from Hong Kong, Taiwan and South Korea has revealed a general unhappiness with the lack of government planning and preparation to meet the needs of migrants who had been actively encouraged to come to New Zealand to help establish links with Asia. Over half had no paid employment in New Zealand. Among those who were currently employed, less than half had been able to obtain jobs related to their previous work experience and skills. Those who wished to do business were dissatisfied with the lack of information about business investment opportunities and the tax system. When it proved impossible to find appropriate employment or set up business in New Zealand in an effort to remain self-reliant, some immigrants chose to leave the family in New Zealand and return to work in their country of origin.
\end{abstract}

Since the implementation of the 1986 immigration policy review, which focussed upon the selection of immigrants on the basis of their personal merits, skills and qualifications irrespective of their race, national or ethnic origin (Burke, 1986), New Zealand has gained a substantial number of new settlers particularly from East Asia. Within this East Asian flow, immigrants from Hong Kong, Taiwan and South Korea have made the major contribution (Lidgard, 1996). Between 1 April 1986 and 31 March 1996, the net gains of people from Hong Kong, Taiwan and South Korea totalled $46,300,21$ percent of total net migration gains of citizens of all countries (excluding New Zealand citizens) to New Zealand during this period.

\section{'Contribution' and 'commitment' of new immi- grants}

Most new immigrants from East Asia are people with professional qualifications, work experience, proven business skills and substantial financial resources. Under the immigration programme adopted since 1986, these immigrants have been sought by the Government because they are seen as bringing with them the links which will help integrate New Zealand politically and economically into the Asian region (Spoonley and Bedford, 1996). However, many East Asian migrants to New Zealand have not found it easy to settle into their new country. A preliminary study based on data from the 1991 Census of Population and Dwellings suggests that half of the Hong Kong Chinese immigrants in Auckland had not been effectively integrated into the workforce (Ho and Farmer, 1994). In 1995, an Auckland University survey of 220 Taiwanese business immigrants shows that almost half had not found a job (New Zealand Herald, 4 July 1995). Another survey carried out by Boyer (1996) in Auckland found that 43 percent of the respondent Taiwanese families were unemployed.
There has been considerable public and political debate about immigration issues during this election year. Notable was the criticism made by the leader of New Zealand First, Winston Peters, of new immigrants' lack of "contribution" and "commitment" to New Zealand (Dominion, 16 February 1996). Peters criticised current immigration policy which brings in people who are not wanting to work in New Zealand: large numbers of immigrants are just "buying" permanent residency, "dumping" their families in New Zealand while they themselves return to their country of origin to work (Dominion, 14 March 1996).

Peters' anti-immigration campaign was interpreted as aiming at Asian migrants, and has brought criticism of racism and xenophobia. Political opponents accused Peters of playing the race card in the election year. Above all, Peters' comments, and the increased public attention he drew to the Asian communities, have done little to enhance positive race relations among ethnic communities. The negative stereotypes of Asian immigrants have to be challenged by informed research if the harmonious integration of migrants into New Zealand's multicultural society is to be achieved.

\section{Two studies}

The migration research staff at the University of Waikato have completed two studies in 1995 and 1996 to explore how East Asian migrants have sought to establish themselves in New Zealand. This research has raised several issues that will need careful consideration and monitoring. In particular, what are the employment prospects for these migrants? What barriers have they faced in relation to setting up business or finding appropriate employment? Have they been forced to make occupational adjustments after coming to New Zealand? How is the employment experience of the East Asians currently living in New Zealand different from 
those who continue to work overseas?

The first study is a questionnaire survey of 124 Chinese and Korean parents of immigrant school children in Auckland. This survey was carried out as part of a larger study on educational and occupational aspirations of East Asian adolescents ${ }^{1}$ (Ho et al, 1996). The material of the second study is derived from 42 in-depth interviews with recent immigrants from Hong Kong, Taiwan and South Korea. The interviews were conducted as part of a larger study into the transformation of migration to New Zealand in the context of restructuring and globalisation (Lidgard, in preparation). Relevant findings of these two studies are discussed in this report.

\section{The questionnaire survey}

The questionnaire survey was conducted in ten secondary schools in Auckland between April and August 1995. Two self-completion questionnaires, one for the students and the other for their parents, were distributed to Chinese and Korean students studying in the sixth and seventh forms. Excluded from the survey were fee-paying students and their parents who were not immigrants. Four hundred and fortyone Hong Kong Chinese, Taiwanese and South Korean students completed the student questionnaire. In addition, 144 parent questionnaires were returned (Ho, 1996). Eighty parent questionnaires were completed by the mothers of the students and 44 were completed by their fathers. The remaining 20 questionnaires were completed by the guardians who were not the students' parents.

In this report, only the questionnaires completed by the Chinese and South Korean parents themselves have been selected for analysis. Of these 124 questionnaires, 67 were returned by Chinese parents from Hong Kong, 39 by Chinese parents from Taiwan and 18 by South Korean parents. The survey cannot claim to provide a fully representative sample of the population of recent East Asian immigrants in Auckland. The biggest obstacle to obtaining respondents' responses was that the questionnaires were sent to the parents through their children in school. As a result, it was possible that some parents might not have received our questionnaires. Furthermore, where both parents were not living in New Zealand at the time of the survey, the questionnaires were unlikely to be returned. Because of the way in which the questionnaires were distributed, it is difficult to generalise from the findings of this survey to the wider population of East Asian migrants who migranted to New Zealand in large numbers after 1986.

However, a reasonable number of recent immigrants from Hong Kong, Taiwan and South Korea took part in the survey. The respondents provided information about their employment experiences in New Zealand, as well as the qualification, employment status and occupation of their spouses, some of whom did not live in New Zealand at the time of the survey. The main characteristics of the East Asians in the survey are discussed in Ho and Chen in this volume (1997). A majority were in the 40-49 age group, and almost half had tertiary education. Over half had lived in New Zealand for under three years. In general, the East Asian surveyed were predominantly recent arrivals in New Zealand and were well educated. Females were younger and had lived in New Zealand longer than males.

As mentioned above, there has been increased public attention to a recent type of immigration from East Asia, in which one or more members of an immigrant family returns to the country of origin to work while the rest of the family, mostly women and children, remains in New Zealand. The term 'astronaut' is popularly used to refer to the returnees who frequently fly back and forth to visit their family in New Zealand. 'Parachute kids' refer to the children being left with one or no parent in New Zealand (Skeldon, 1994a).

In this study, 44 percent of East Asian males and 9 percent of the females reported that they lived overseas for most of the time in a year (Table 1). The occupation and employment of these 'astronauts', as well as those East Asians who were currently living in New Zealand, was examined. Besides, among those East Asians who had paid employment in New Zealand, their occupations before and after migration were explored. In most cases, separate analyses were made for the two sexes.

\section{Employment status}

Table 2 presents the employment status of the East Asians who lived in New Zealand and those who lived overseas. Forty-six percent of East Asian males and 73 percent of the females who lived in New Zealand were not actively participating in the labour market, while 11 and 4 percent respectively were actively seeking employment. Among those who had paid employment in New Zealand, more males were self-employed rather than working for wages or salary, whereas more females were wage or salary earners rather than self-employed.

Compared with the East Asian migrants who lived in New Zealand, much larger proportions of the male 'astronauts' who lived overseas had paid employment. Only 20 percent were not actively participating in the labour market. This finding is hardly surprising. In the past half century, much of the Asian region has undergone a significant transformation changing the region from third world status into an 'economic powerhouse in the world economy' (So and Chiu, 1995, 3). Average growth rates in GDP in Hong Kong, Taiwan and South Korea have been between six and eight percent over the 25 years from 1965 to 1990 (Asia Yearbook, 1992; World Bank, 1992 in Skeldon, 1994b). Unemployment is 'virtually non-existent in the East Asian economies' (Skeldon, 1994b, 185), whereas in Canada, Australia and New Zealand unemployment exceeded 10 percent at the

Table 1. Current residence of the East Asians in the survey

$\begin{array}{lrrrr}\text { Current Residence } & \text { Number } & \% & \text { Number } & \% \\ \text { New Zealand } & 70 & 56.5 & 113 & 91.1 \\ \text { Overseas } & 54 & 43.5 & 11 & 8.9\end{array}$


beginning of the 1990 s. Because of the relatively poor employment conditions in New Zealand, many East Asians are unwilling to give up their well-paid jobs or business ventures in their country of origin, although they have also made a decision to emigrate to give their children security and a better future.

The employment status of female 'astronauts' differs from that of their male counterparts. Only two female astronauts had paid employment overseas. The remaining nine were not working.

\section{Occupation}

The current occupation of the East Asians who lived in New Zealand and those who lived overseas is presented in Table 3. Most 'astronauts' who had paid employment overseas were working in the managerial, professional and technical sectors. In comparison, much lower percentages of the East Asians in New Zealand worked as administrators, managers, professionals and technicians.

Although existing immigration policies are designed to attract highly skilled and educated people to New Zealand, it has not been easy for the new settlers to find work in New Zealand where their previous work experience and skills are fully utilised. In March, a Medical Council survey has revealed that more than 600 immigrant doctors were not working in the profession (New Zealand Herald, 14 March
1996). A Masters research study at Victoria University of Wellington of 22 immigrant engineers, teachers and health professionals also showed that only few of the new settlers who were interviewed had found work in their own profession (Barnard, 1996). As found by the Department of Internal Affairs (1996), some of the barriers faced by recent immigrants to finding work in New Zealand include: a lack of English, overseas qualifications not being recognised and not having New Zealand work experience.

One of the aims of our survey was to explore if the East Asians in New Zealand have been able to obtain jobs which are related to their pre-migration work experience and skills. Information regarding occupation before and after migration of the East Asians ( 70 males and 113 females) who were living in New Zealand at the time of the survey were analysed. The results are presented in Table 4.

Prior to migration, a majority of the East Asian males were in the labour force. Most had administrative and professional occupations. After migration, 60 percent had no paid employment. Over half had not been able to obtain work in the administrative and professional sectors. Among the females, half were not working prior to migration. The proportion of women who were not actively engaged in the labour force increased to nearly 80 percent after migration. Like their male counterparts, many of the women who had found work in New Zealand experienced downward mobility.

\section{Table 2. Employment Status of East Asians by gender and current residence}

\begin{tabular}{lcccccc}
\hline & \multicolumn{3}{c}{ Males } & \multicolumn{3}{c}{ Females } \\
Employment Status & $\begin{array}{c}\text { Live in NZ } \\
\%\end{array}$ & $\begin{array}{c}\text { Overseas } \\
\%\end{array}$ & $\begin{array}{c}\text { Total } \\
\%\end{array}$ & $\begin{array}{c}\text { Live in NZ } \\
\%\end{array}$ & $\begin{array}{c}\text { Overseas } \\
\%\end{array}$ & $\begin{array}{c}\text { Total } \\
\%\end{array}$ \\
\hline Wage or salary earners & 18.6 & 18.5 & 18.5 & 15.9 & 9.1 & 15.3 \\
Self-employed & 21.4 & 44.5 & 31.5 & 6.2 & 9.1 & 6.5 \\
Seeking employment & 11.4 & 0 & 6.5 & 4.4 & 0 & 4 \\
Not actively engaged & 45.7 & 20.4 & 34.7 & 72.6 & 81.8 & 73.4 \\
Not stated & 2.9 & 16.6 & 8.8 & 0.9 & 0 & 0.8 \\
Total Number & 70 & 54 & 124 & 113 & 11 & 124 \\
\hline
\end{tabular}

Table 3. Current occupation of East Asians by gender and current residence

\begin{tabular}{lcccccc}
\hline & \multicolumn{3}{c}{ Males } & \multicolumn{3}{c}{ Females } \\
Occupation & $\begin{array}{c}\text { Live in NZ } \\
\%\end{array}$ & $\begin{array}{c}\text { Overseas } \\
\%\end{array}$ & $\begin{array}{c}\text { Total } \\
\%\end{array}$ & $\begin{array}{c}\text { Live in NZ } \\
\%\end{array}$ & $\begin{array}{c}\text { Overseas } \\
\%\end{array}$ & $\begin{array}{c}\text { Total } \\
\%\end{array}$ \\
\hline Administrators \& managers & 15.7 & 40.7 & 26.6 & 4.3 & 9.1 & 4.9 \\
Professionals & 2.9 & 7.4 & 4.9 & 4.3 & 9.1 & 4.9 \\
Technicians & 8.6 & 1.9 & 5.6 & 1.8 & 0 & 1.6 \\
Clerks & 2.9 & 0 & 1.6 & 2.7 & 0 & 2.4 \\
Service and sales workers & 5.7 & 0 & 3.2 & 2.7 & 0 & 2.4 \\
Trades workers & 2.9 & 0 & 1.6 & 2.7 & 0 & 2.4 \\
Plant \& machine operators & 0 & 0 & 0 & 1.8 & 0 & 1.6 \\
Occupations not classifiable & 1.3 & 13 & 6.5 & 1.8 & 0 & 1.6 \\
No occupation* & 60 & 37 & 50 & 77.9 & 81.8 & 78.2 \\
\hline Total Number & 70 & 54 & 124 & 113 & 11 & 124
\end{tabular}

* Includes seeking employment, not actively engaged and not stated 
Table 4. East Asians in New Zealand, occupation Before and After Migration

\begin{tabular}{|c|c|c|c|c|}
\hline \multirow[b]{2}{*}{ Occupation } & \multicolumn{2}{|c|}{ Males } & \multicolumn{2}{|c|}{ Females } \\
\hline & $\begin{array}{r}\text { Before } \\
\%\end{array}$ & $\begin{array}{r}\text { After } \\
\%\end{array}$ & $\begin{array}{c}\text { Before } \\
\%\end{array}$ & After \\
\hline Administrators \& managers & 58.6 & 15.7 & 10.6 & 4.3 \\
\hline Professionals & 18.6 & 2.9 & 21.2 & 4.3 \\
\hline Technicians & 5.7 & 8.6 & 4.4 & 1.8 \\
\hline Clerks & 4.2 & 2.9 & 5.3 & 2.7 \\
\hline Service and sales workers & 0 & 5.7 & 0.9 & 2.7 \\
\hline Trades workers & 2.9 & 2.9 & 1.8 & 2.7 \\
\hline Plant \& machine operators & 1.4 & 0 & 0 & 1.8 \\
\hline Occupations not classifiable & 2.9 & 1.3 & 0.9 & 1.8 \\
\hline No occupation* & 5.7 & 60 & 54.9 & 77.9 \\
\hline Total Number & 70 & 70 & 113 & 113 \\
\hline
\end{tabular}

Specifically, only 19 East Asians had been able to obtain employment in New Zealand which was equivalent to the work they were doing before migration. Large numbers had obtained work where their previous qualifications, work experience and skills could hardly be utilised. Among them a doctor was working as a motel manager, an accountant working as a child care worker, an import and export manager working as an office clerk, an office clerk working as a cook, and a builder working as a cashier.

Contemporary international literature on unemployment has demonstrated that unemployment, underemployment and other adverse labour market experiences are associated with poor mental health, not only for the unemployed people but also their families (Fryer, 1995; McKee and Bell, 1986; McLoyd, 1989). As will be shown in the next section, the economic and occupational dislocation experienced by many newly arrived East Asians in New Zealand is very disruptive to family life and hinders their adaptation process.

\section{In-depth interviews}

In this section, the post-migration employment experiences of the recent immigrants from Hong Kong, Taiwan and South Korea are further explored using material derived from 42 in-depth interviews. These interviews were conducted between November 1995 and February 1996 (Lidgard, 1996). All respondents who were interviewed had arrived in New Zealand after the 1986 immigration policy review. Most migrants from South Korea and Taiwan had entered under the points system on the basis of their qualifications and skills. Those from Hong Kong had mostly gained entry on the business investment potential they offered.

The respondents ranged in age from early 20 s to late 60 s and were engaged in a wide range of occupations. Some were still students or retraining, and two of the older women were care-givers for the family. Most relied on interest from deposits rather than on a salary or wages as their primary source of income, although those who had been in New
Zealand for a longer period of time were more likely to be self-employed or working as employees. The respondents' period of permanent residence in New Zealand ranged from one month to seven years.

It should be noted that just before the interviews were conducted immigration policy was 'fine-tuned' for 'targeted imigrants' in October 1995. These changes that were introduced require applicants to obtain professional registration before qualifying for immigration points equivalent to their qualifications; meet a required minimum standard of English or pay a fee; and award immigration points for New Zealand work experience and increased points for a job offer (New Zealand Immigration Service, 1995). These amendments address some of the problems that were uncovered by this survey although for the East Asians already in the country, their problems of finding employment and setting up business in New Zealand have yet to be overcome.

\section{Finding employment}

Although many new immigrants arrive knowing that unemployment levels are high in New Zealand, the reality is still more difficult than they imagined. "We wouldn't be able to get permission to build a factory as New Zealand wants to keep its 'clean, green' image. I agree with this as we came for the environment but if I could get a job it would be better", said a respondent newly arrived from South Korea.

There is a major concern among most respondents at the lack of government policy to make use of the experience and skills being brought by the new immigrants. Immigrants from South Korea and Taiwan are particularly concerned about the lack of recognition of their overseas qualifications. As a Korean respondent said:

\begin{abstract}
"We want qualification to be admitted here. Many friends are well qualified with wide experience. New Zealand could use their expertise but at present there is no link or bridge to get the most of their experiences. The New Zealand Government should solve that problem. What is the point of bringing music conductors and Drs of Medicine here to work at gas station? Not so bad for businessmen as they can do anything but new immigrants should be able to use their experience. The government should take a more flexible policy or system to accommodate new immigrants."
\end{abstract}

The recognition of qualifications, however, is just the first step and many feel that even if their qualifications are accepted, the reality is that employers will always choose to give jobs to locally trained people with local work experience if they have the choice. As another respondent from South Korea said:

When in Korea I thought I had a bright future. The reality in New Zealand is quite different. Even if you speak fluent English it would be difficult to find work. I feel you need to plan to study for four to five years for new qualifications to find work. Even if my qualifications as a chemical engineer were approved I wouldn't be able to 
get a job as a chemical engineer. The Government hasn't planned for the new immigrants.

Upgrading skills is one route some are using into employment in New Zealand. For example, the wife of a respondent from Taiwan returned to University when she settled in Hamilton six years ago. Three years later she graduated with a Masters Degree in Computing and Mathematical Sciences and is now working as a systems engineer in a government department.

Obviously, however, it is a much happier situation for immigrants when they obtain employment using previous skills and work experience. Two of the respondents from Hong Kong are working as paid employees of New Zealand companies without needing to upgrade their qualifications. One of them is employed as a skilled designer in the garment industry, the type of work he has done all his working life prior to migration. The other had worked in the banking industry in Hong Kong for nearly twenty years before coming to New Zealand. Shortly after she arrived, she obtained part-time work on contract. She said that this first step into work in New Zealand was the most difficult. Now she is employed by a New Zealand bank in a full-time position of responsibility.

However, those who are still unable to find a job feel that they are not really settled in New Zealand until they have obtained employment which suits their previous work experience and qualifications. "Employees are chosen on race rather than qualifications" is the feeling of one Korean respondent. He felt that even when new arrivals were reasonably fluent in English it was still difficult for them to obtain a job. "Even when people have been employed by a kiwi company when redundancies occur the Koreans are the first to go". He cited examples he knew amongst members of the congregation of the church he attends. "Some people, who have been studying hard for qualifications, give up when they hear these stories".

\section{Setting up business}

Business investors from East Asia complained about the lack of published guidelines on general business regulations and tariffs - information they felt should have been prepared for them before their applications for permanent residence were accepted. These respondents felt that the government was expecting them to invest their money in New Zealand but was not prepared to spend any money to help them establish themselves successfully once they had arrived. One Korean said he felt the New Zealand Government was acting like "pirates".

The small market, and the monopoly of the producer boards on the export of primary products, are additional difficulties immigrants have had to face when trying to set up businesses in New Zealand. As one Taiwanese said:

We would like our whole family to get together but it is not easy for my husband to find a job. The New Zealand Government wish businessmen to bring skills - but there are few chances to do business although my husband can speak English fluently and is a very experienced businessman. He has tried for several years as he would like to stay and pay taxes. Small market the problem. Only things we can export are agricultural products and there's a monopoly problem.

Despite the difficulties mentioned, a number of business ventures have been set up in New Zealand by a few respondents from all three countries. These businesses include food stores, amusement parlours and general import and export ventures. A number of respondents reported that many new families from East Asia have made a genuine effort to establish themselves in a business in New Zealand but, after seeing others lose a considerable amount of money in failed business ventures, they decided they could not afford to stay. Hong Kong families appear to move on to other countries, such as Australia, whereas a Korean in his 40 s suggested that younger Koreans, who have not yet built up equity to remain living on their capital, have been forced to give up trying to establish themselves in New Zealand and return to South Korea. Some mentioned, however, that return is not a viable option. As one Korean noted:

Many immigrant people think that they need to go back but they can't. They have sold their houses and left their jobs and it is too difficult to return. Korean society is so competitive they can't get back in the same level as they were when they left.

\section{'Astronauts' and work overseas}

When it has proved impossible to find a job or set up a business in New Zealand, an alternative strategy that some families have chosen is for the husband to buy a house, settle his wife and children and then return to continue his business ventures in the country of origin. This 'astronaut' arrangement, however, places a great strain on the family as a unit. It adds the burden of family separation to the already significant challenge of adjustment to a completely new culture and language. The women who were interviewed always mentioned that they could not be completely satisfied with their New Zealand life while they remained separated from their husbands for a large part of the year.

International literature has shown that 'astronaut' migration is also very much part of the contemporary Chinese migration to Australia (Kee and Skeldon, 1994) and Canada (Lam, 1994). As a recent study on Hong Kong 'astronaut' families in Australia shows, the 'astronaut' strategy is 'a strategy for coping with unemployment or underemployment, or with the potential or actual loss of elite status in Australia' (PePua et al, 1996, 50).

In New Zealand, the 'astronaut' strategy has received critical comment from some politicians who view this arrangement as evidence of Asian immigrants' lack of contribution and commitment to New Zealand. This type of comment fails to acknowledge that many new immigrants are willing to work at whatever job they can find here in New Zealand to support their families. Family separation is not a preferred option for 
the East Asian migrants, but is considered a better alternative to not working and being forced to live on welfare payments.

\section{Future research}

The two studies reported in this paper were part of a larger research programme into contemporary population change in New Zealand which was funded by a grant from the Foundation for Research, Science and Technology. The studies provide useful information about immigration and adaptation in New Zealand from the point of view of the immigrants themselves. However, because of the small number of families involved, it is difficult to generalise from the findings of small-scale surveys to the wider population of recent immigrants. The analysis of data collected on migrants in the 1996 Census of Population and Dwellings will allow for more broadly based inquiries into the participation of recent immigrants in New Zealand's workforce and society.

There has been little New Zealand-based research on the impact of business immigration on New Zealand's development. As our studies revealed, some of the East Asian business migrants have set up businesses in New Zealand. Some continue to run their businesses back in their home countries while maintaining social and economic linkages with families in New Zealand. A key question here is: do the entrepreneurial activities of the return migrants substitute for business and employment opportunities in New Zealand, or are these activities designed to further their chances of making a more effective contribution to economic development in New Zealand? With the growing economic importance of Asia to New Zealand, research is needed to study the entrepreneurial activities of the Asian migrants who have come to New Zealand under the business immigration programmes adopted since 1986, and explore how these activities may help New Zealand develop its economic and business ties with Asia.

\section{Acknowledgements}

This study forms part of two larger research projects, the Demographic Crossroads Programme and the New Demographic Directions Programme, which are being carried out at the University of Waikato with financial support from the Foundation for Research, Science and Technology. The authors wish to acknowledge the assistance received from members of the Hong Kong Chinese, Taiwanese and South Korean communities in Auckland and Hamilton who participated in the research. The advice, support and assistance of Professor Richard Bedford, Co-ordinator of the migration projects, and Ms Joanne Young and Ms Yunn-Ya Chen, members of the research team is gratefully appreciated.

\section{Note}

1. A brief report of the study on East Asian adolescents is presented at LEW7 (Ho and Chen, 1997).

\section{References}

Asia Yearbook 1992 Far East Economic Review.

Barnard, R. 1996 What issues do recent immigrants face in
New Zealand? A qualitative study of three professional groups: health professionals, engineers and teachers. Unpublished Masters thesis, Victoria University of Wellington, Wellington.

Boyer, T. 1996 Problems in Paradise: Taiwanese immigrants to Auckland, New Zealand. Asia Pacific Viewpoint 37(1):59-79.

Burke, K. 1986 Review of immigration policy, August 1986 Appendices to the Journal of the House of Representatives G42, Government Printer, Wellington.

Department of Internal Affairs 1996 High Hopes: A survey of qualifications, training and employment issues for recent immigrants in New Zealand. Ethnic Affairs Service. Information series No. 2 Local Government and Community services. Department of Internal Affairs.

Fryer, D. Labour market disadvantage, deprivation and mental health: benefit agency? The Psychologist June: $265-272$.

Ho, E.S. 1996 Researching post-school education and employment choices among Asian adolescent migrants: A report on methodological issues Population Studies Centre Discussion Paper Number 14, University of Waikato, Hamilton.

Ho, E.S. and Chen, Y.Y. 1997 Post-school employment choices of East Asian adolescent migrants. In Morrison, P.S. (ed.) Labour, Employment and Work in New Zealand, Proceedings from the Seventh Conference, VictoriaUniversity of Wellington.

Ho, E.S., Chen, Y.Y., Kim, S.N. and Young, J. 1996 In search of a better future: Report of a survey on post-school education and employment choices among Asian adolescent migrants Population Studies Centre Discussion Paper Number 17. University of Waikato, Hamilton.

Ho, E.S. and Farmer, R. 1994 The Hong Kong Chinese in Auckland. In Skeldon, R (ed) Reluctant Exiles? Migration from Hong Kong and the New Overseas Chinese M.E. Sharpe, New York, 183-196.

Kee, P. and Skeldon, R. 1994 The migration and settlement of Hong Kong Chinese in Australia. In Skeldon, R (ed) Reluctant exiles? Migration from Hong Kong and the new overseas Chinese M.E. Sharpe, New York, 183-196.

Lam, L. 1994 Searching for a safe haven: The migration and settlement of Hong Kong Chinese immigrants in Toronto. In Skeldon, R (ed) Reluctant exiles? Migration from Hong Kong and the new overseas Chinese M.E. Sharpe, New York, 163-179.

Lidgard, J.M. 1996 East Asian migration to Aotearoa/New Zealand: Perspectives of some new arrivals Popu- 
lation Studies Centre Discussion Paper Number 12, University of Waikato, Hamilton.

Lidgard, J.M. in preparation International migration, globalisation and a decade of population change in Aotearoa/New Zealand. Unpublished D Phil thesis, University of Waikato, Hamilton.

McKee, L. And Bell, C. 1986 His unemployment, her problem: the domestic and marital consequences of male unemployment. In Allen, S, Watson, S, Purcell, $\mathrm{K}$ and Wood, S (eds) The experience of unemployment Macmillan, Basingstoke.

McLoyd, V.C. 1989 Socialisation and the development in a changing economy: the effects of parental job and income loss on children American Psychologist 44(2): 293-302.

New Zealand Immigrant Service 1995 New Zealand's Targeted Imigration Policies New Zealand Immigration Service.

Pe-Pua, R, Mitchell, C, Iredale, R and Castles, S. 1996 Astronaut families and parachute children: The cycle of migration between Hong Kong and Australia Centre for Multicultural Studies, University of Wollongong.

Skeldon, R. 1994a Reluctant exiles? Migration from Hong Kong and the new overseas Chinese M.E. Sharpe, New York

Skeldon, R. 1994b East Asian migration and the changing world order. In Gould, W T S and Findlay, A M (eds) Population migration and the changing world order John Wiley and Sons, Chichester, 173-193.

So, A.Y. and Chiu, S.W.K. 1995 East Asia and the world economy Sage Publications, Thousand Oaks, California.

Spoonley, P. And Bedford, R. 1996 Issue Paper: Aotearoa/New Zealand, Paper to First International Meeting of the Asia-Pacific Migration Research Network, Chulalongkorn University, Bangkok, 11-13 March 1996.

\section{Authors}

Elsie Ho and Jacqueline Lidgard are research fellows in the Department of Geography at the University of Waikato, Private Bag 3105, Hamilton. 